\title{
INTERACTION BETWEEN NATIVE AND ALIEN SPECIES OF CRAYFISH IN AUSTRIA: CASE STUDIES.
}

\author{
M. PÖCKL (1), R. PEKNY (2)
}

(1) Institute of Ecology and Conservation Biology, Department of Limnology, University of Vienna. State Government of Lower Austria, Landhausplatz 1, A-3109 ST. PÖLTEN, Austria. E-mail : Manfred.Poeckl@ noel.gv.at.

(2) Stixenlehen 8, A-3345 GÖSTLING AN DER YBBS, Austria.

E-mail : Reinhard.Pekny@aon.at.

\begin{abstract}
In Austria, three indigenous crayfish species occur: the noble crayfish (Astacus astacus), the stone crayfish (Austropotamobius torrentium), and the white-clawed crayfish (Austropotamobius pallipes). It is not known if Astacus leptodactylus is autochthonous in the very eastern part of Austria, near the border with Hungary and Slovakia. In other parts of Austria the Turkish crayfish has been transplanted into several gravel pits and ponds. Up to now, the red swamp crayfish (Procambarus clarkii) is not known to occur in the wild, but can be bought alive in fish markets, restaurants, and the aquarium trade. The Nearctic spiny-cheek crayfish (Orconectes limosus) and the signal crayfish (Pacifastacus leniusculus) have been introduced since the 1970s by crayfish farmers because these species are resistant to the crayfish plague fungus (Aphanomyces astaci). There are just a few populations of $O$. limosus, and the species is not spreading actively. However, $P$. leniusculus is widespread all over Austria, and was illegally introduced from one water body to another. It can be characterized as an aggressive, invasive North American species, spreading actively and acting as a vector of the crayfish plague. Unfortunately the habitat requirements of the native noble crayfish and the alien signal crayfish are nearly the same. Case studies are given in the following chapters: the first group of examples refers to water bodies where the alien signal crayfish is most probably the cause of displacement of the indigenous noble crayfish: 1) Hintersee, 2) Irrsee («Zeller See »), 3) north-western Lower Austria (« Waldviertel »), 4) Merzenstein (aquacultural enterprise), 5) Neufelder See. The second group of examples refers to water bodies where alien and indigenous species are able to coexist: a) the confluence of the main course of the Danube River, the Ölhafen and the Neue Donau in the southeast part of Vienna, b) the Schönauer Wasser, a backwater of the Danube River downstream Vienna, c) backwaters and ox bows of the Morava River. The differences between these two groups are analysed, and it is speculated on possible causes allowing coexistence. Some conclusions are drawn. Important actions related to the protection of native crayfish are briefly discussed.
\end{abstract}

Key-words : alien crayfish, indigenous crayfish, displacement, coexistence, case studies, Austria. 


\section{LES INTERACTIONS ENTRE LES ÉCREVISSES NATIVES ET LES ÉCREVISSES EXOTIQUES EN AUTRICHE : ÉTUDES DE CAS.}

\section{RÉSUMÉ}

En Autriche, trois espèces d'écrevisses indigènes existent: l'écrevisse à pattes rouges (Astacus astacus), l'écrevisse des torrents (Austropotamobius torrentium), et l'écrevisse à pattes blanches (Austropotamobius pallipes). II n'est pas incertain que l'écrevisse à pattes grêles (Astacus leptodactylus) soit autochtone à l'extrême est de l'Autriche près de la frontière de la Hongrie et de la Slovaquie. Dans tout le reste du pays, l'homme a implanté $A$. leptodactylus dans certains étangs et certaines gravières. Jusqu'à maintenant, l'écrevisse rouge de Louisiane (Procambarus clarkil) est inconnue en liberté en Autriche, mais il est possible d'acheter les exemplaires vivants de cette écrevisse exotique dans les poissonneries, les restaurants et les animaleries. L'écrevisse américaine (Orconectes limosus) et l'écrevisse signal (Pacifastacus leniusculus) ont été introduites depuis les années 1970 par quelques astaciculteurs autrichiens parce que ces espèces sont résistantes à l'aphanomycose (Aphanomyces astaci). On trouve quelques populations d'O. limosus en Autriche et elles ne se propagent pas activement. Par contre, P. leniusculus se répand à travers toute l'Autriche et elle est introduite illégalement d'un cours d'eau à un autre. Cette dernière est caractérisée comme une espèce agressive et invasive d'Amérique du Nord comme vecteur actif de l'aphanomycose. Malheureusement, le profil requis de l'habitat de l'écrevisse native à pattes rouges ne différe pas beaucoup de l'écrevisse signal. Cet article présente quelques études de cas: le premier groupe concerne des exemples choisis dans quelques plans et cours d'eau où l'écrevisse signal a supplanté totalement l'écrevisse à pattes rouges (ou l'écrevisse à pattes grêles) au cours de ces dernières années : 1) Hintersee, 2) Irrsee («Zeller See »), 3) le nord-ouest de l'Autriche-Bas («Waldviertel»), 4) Merzenstein (une entreprise d'aquaculture), 5) Neufelder See. Le deuxième groupe concerne des exemples choisis dans quelques plans et cours d'eau où les écrevisses indigènes et exotiques sont capables de coexister : a) le confluent du fleuve principal du Danube, l'Ölhafen et le Neue Donau au sud-est de Vienne, b) le Schönauer Wasser, un bras secondaire du Danube en aval de Vienne, c) quelques bras secondaires de rivière du Morava. Les différences entre ces catégories sont analysées et les raisons possibles qui permettent cette coexistence sont présentées. On en déduit quelques conclusions. Les actions nécessaires par rapport à la préservation des espèces d'écrevisses natives sont discutées rapidement.

Mots-clés : écrevisses exotiques, écrevisses indigènes, élimination, coexistence, Autriche.

\section{INTRODUCTION}

Because the impacts of invasive alien species are immense, insidious, and often irreversible, these invasive alien species are now recognized as one of the greatest biological threats to our planet's ecological and economic well-being (MOONEY and HOBBS, 2000; PERRINGS et al., 2000; PIMENTEL et al., 2000). Addressing the problem of invasive alien species is urgent because the threat is growing daily and the economic and environmental impacts are severe (MC NEELEY, 2000).

Numerous international instruments, binding and non-binding, have been developed to deal with at least certain aspects of the problem of invasive alien species. The most comprehensive is the 1992 Convention on Biological Diversity (CBD), which calls on its parties - numbering 178 governments in 2000 - to « prevent the introduction of, control or 
eradicate those alien species which threaten ecosystems, habitats, or species 》 (Article 8h). The Global Invasive Species Programme (GISP) was created in 1997 to provide information to implement Article $8(\mathrm{~h})$ of the CBD. This programme is operated by a consortium of the Scientific Committee on Problems of the Environment (SCOPE), CAB International (CABI), the World Conservation Union (IUCN), and the United Nations Environment Programme (UNEP). The goal of GISP is to use the best practices available to control invasive alien species and to disseminate information to serve the higher goal of conserving global biodiversity and mitigating problems caused by invasive organisms on a worldwide scale. GISP also recognizes that it is dealing with dynamic ecosystems, not static ones; and it has no intention of trying to « freeze » any particular ecosystems in an imagined pristine state. Rather, it realizes that active management of human effects on ecosystems is required in a time of increasing human impacts. This strategy (Phase I) is designated to define the problem, describe its dimensions, discuss its implications, identify those economic sectors that should be involved in action, suggest approaches to management, and recommend appropriate strategies to the responsible agencies (MC NEELEY, 2000).

The present article describes the problems alien crayfish species from North America are causing to the indigenous European crayfish fauna. There was a general agreement among astacologists in the Florence Workshop (GHERARDI and HOLDICH, 1999) and the Lausanne Resolution signed during the $7^{\text {th }}$ Symposium of the International Association of Astacology (IAA, 1988), as published in Freshwater Crayfish 7, that the indigenous European crayfish fauna is threatened by introduced invasive alien species from North America. In Europe, the situation for the alien species is good as they steadily increase their distribution, while for the native species the situation, in general, is very bad (LINDQVIST, 1988). The main threat to native crayfish is the spread of the alien species as they act as a vector for the crayfish plague fungus, Aphanomyces astaci (Schikora, 1903) (DIÉGUEZ-URIBEONDO and SÖDERHÄLL, 1993) and also otherwise outcompete the European species (e.g. SÖDERBÄCK, 1995; HOLDICH et al., 1999). Unfortunately, any national regulation against the import of living crayfish from foreign countries is illegal within the European Community framework due to the principle of Free Trade (EUROPEAN COURT OF JUSTICE, 1994). The spread of alien crayfish species is by both natural migration and, more importantly, by man.

In 1890, the primary trans-continental introduction of the spiny-cheek crayfish, Orconectes limosus (Rafinesque, 1817), and the signal crayfish, Pacifastacus leniusculus (Dana, 1852), from North America into Europe was performed, and in 1970 crayfish imported from North America were released into a number of Austrian water bodies. The material for the second stocking experiments of Austrian waters with signal crayfish came from the Swedish Simontorps Akvatiska Avelslaboratorium (SPITZY, 1971, 1973). These import and introduction activities were not only undertaken by private entrepreneurs and managers, but also by leading officers of the Austrian Federal Fisheries Institute of the Ministry of Agriculture. After these primary trans-continental introductions, aliens were illegally introduced from one water body to another (secondary introductions). These occurred deliberately, but many people were - and still are - not aware neither of the crayfish fauna nor the legislation concerning crayfish.

In Austria, three native crayfish species occur: the noble crayfish, Astacus astacus (Linnaeus, 1758), the stone crayfish, Austropotamobius torrentium (Schrank, 1803), and the white-clawed crayfish, Austropotamobius pallipes (Lereboullet, 1858). It is not known if the Turkish crayfish, Astacus leptodactylus (Eschscholtz, 1823), is autochthonous in the very eastern part of Austria, near the border to Hungary and Slovakia. In other parts of Austria the Turkish crayfish has been transplanted into several gravel pits and ponds. Up to now, the red swamp crayfish, Procambarus clarkii (Girard, 1852), is not known to occur in the wild in Austria, but can be bought alive in fish markets, restaurants, and the aquarium trade. Hence, the danger is extremely high that it will sooner or later escape from 
enclosures or be transplanted into ponds or running waters by hobby aquarists who keep exotic animals as pets.

Crayfish distribution and abundance as well as outbreaks of the crayfish plague were extremely poorly known until 1998 when the distribution data were - after intensive mapping and monitoring activities - compiled for the first time at a national scale (PÖCKL, 1999a). In Austria, there is now, in general, quite a good overview of the situation, although there are still some areas with very little information (PÖCKL, 2002).

In the following sections first-hand case studies, personal observations of at least one of the authors, are presented: the first group of examples refers to water bodies where the alien signal crayfish has totally displaced the native noble crayfish. The second group of examples refers to water bodies where alien and indigenous species are able to coexist. The differences between these two groups are analysed, and it is speculated on possible causes allowing coexistence.

\section{RESULTS}

\section{Displacement of native crayfish species by $P$. leniusculus}

\section{Hintersee}

The Hintersee, a natural lake, is situated 17 kilometres southeast of the famous city of Salzburg (Figure 1) at an altitude of $688 \mathrm{~m}$ above sea level (longitude: $13^{\circ} 15^{\prime} \mathrm{E}$, latitude: $47^{\circ} 45^{\prime} \mathrm{N}$ ). As this small (length: $1.4 \mathrm{~km}$, width: $0.7 \mathrm{~km}$, surface area: $70 \mathrm{ha}$, maximum depth: $22 \mathrm{~m}$, mean depth: $7 \mathrm{~m}$ ), mesotrophic lake is also used partly as a reservoir to produce hydroelectric power, the water level fluctuates by between 1 and $1.5 \mathrm{~m}$.

Some 25 years ago, a forest-officer who also managed the fisheries of this lake, stocked noble crayfish ( $A$. astacus). The attitude of this man towards the native crayfish was remarkable because in the 1970s the import and introduction activities of North American crayfish species were booming.

The Hintersee, however, has been inhabited for many years by a healthy population of $A$. astacus. In 1994, the forest-officer was very worried and reported that a small pond within the drainage system of the Hintersee had been stocked with signal crayfish ( $P$. leniusculus) by anglers. How justified his apprehension had been became known one year later (1995) when the first specimen of $P$. leniusculus were observed in the Hintersee. On November $6^{\text {th }} 1999$, starting at 7.00 p.m., crayfish were harvested quantitatively by hand by scuba-diving along several transects. The temperature of the air and the water was $4^{\circ} \mathrm{C}$ and $8^{\circ} \mathrm{C}$, respectively, and animals were still very active at this time of the year. Species, sex, total body length, carapace length, wet weight and peculiarities were noted. An area of $1600 \mathrm{~m}^{2}$ was inspected and 99 crayfish were caught: 98 P. leniusculus (total body length ranging from 7.0 to $15.5 \mathrm{~cm}$, with an average length of $10.6 \mathrm{~cm}$; weight ranging from $7.5 \mathrm{~g}$ to $150 \mathrm{~g}$, with an average weight of $39.49 \mathrm{~g}$ ) and 1 A. astacus (male; total body length of $16.0 \mathrm{~cm}$ ). Some animals had missing antennae or claws. It is not known, however, if there was an outbreak of the crayfish plague. All the crayfish were caught along the shoreline up to a maximum depth of five metres on coarse substrate. No crayfish were caught at a depth in excess of five metres on fine particulate lake sediment.

The fisheries management aims to reverse this relationship at the long term by removing as many signal crayfish from the lake as possible and by re-introducing noble crayfish. 


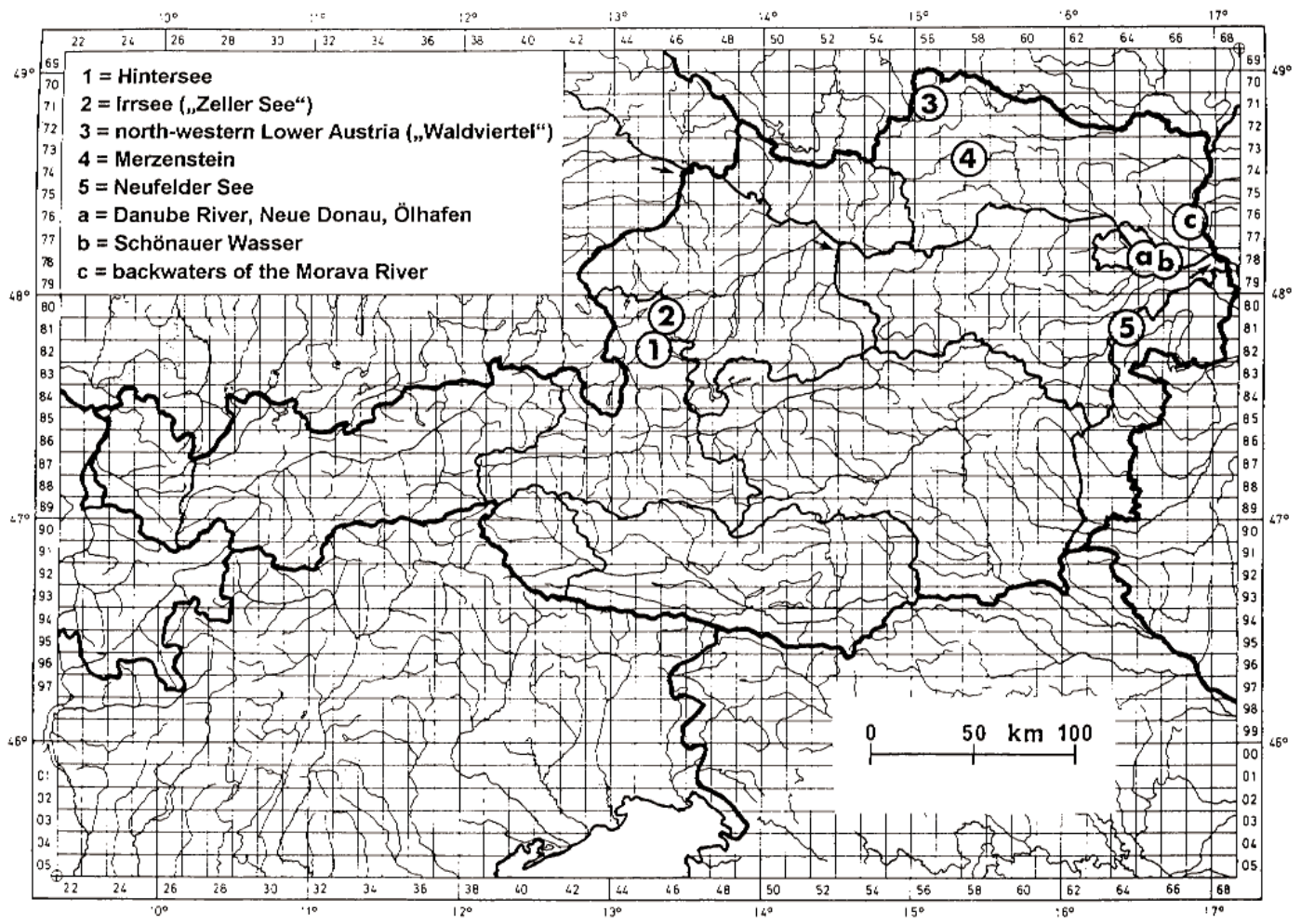

Figure 1

The location of the sites where the case studies were done. Also shown are the nine federal states (Bundesländer) in the Federal Republic of Austria. 1 = Hintersee, 2 = Irrsee ( Zeller See »), 3 = north-western Lower Austria ("Waldviertel »), 4 = Merzenstein, aquacultural enterprise, 5 = Neufelder See; $a=$ confluence of the main course of the Danube River, the Ölhafen, and the Neue Donau, $b=$ the Schönauer Wasser, a backwater of the Danube River, $c=$ backwaters or ox bows of the Morava River. Arrows show flow direction of the Danube River.

\section{Figure 1}

Position des sites d'observation. Les neuf " länder " de la République Fédérale d'Autriche sont présentés. 1 = Hintersee, 2 = Irrsee ("Zeller See »), 3 = nord-ouest de l'Autriche-Bas ("Waldviertel »), 4 = Merzenstein, entreprise d'aquaculture, 5 = Neufelder See ; $a=$ confluence du fleuve principal du Danube, de l'Ölhafen, et de Neue Donau, $b=$ Schönauer Wasser, un bras secondaire du Danube, $c=$ bras secondaire du Morava. Les flèches signalent la direction du courant du Danube.

\section{Irrsee («Zeller See »)}

The Irrsee (also called « Zeller See »), a natural lake, is located in southwest Upper Austria near the border to Salzburg (Figure 1) at an altitude of $553 \mathrm{~m}$ above sea level (longitude: $13^{\circ} 19^{\prime} \mathrm{E}$, latitude: $47^{\circ} 54^{\prime}-56^{\prime} \mathrm{N}$ ). This mesotrophic lake which has no considerable surface feeder is draining into the Mondsee, its outlet being called the Zeller Ache. The lake has a length of $4.4 \mathrm{~km}$, a width of $1 \mathrm{~km}$ and a maximum depth of $32 \mathrm{~m}$, the mean depth being $15 \mathrm{~m}$. The surface area is 355 ha.

During the second half of the $20^{\text {th }}$ century the Irrsee has been successfully stocked with the Turkish crayfish (A. leptodactylus) and the population was thriving well until 1998, 
when the first signal crayfish ( $P$. leniusculus) was discovered. The origin of the alien crayfish is, however, unknown, but well-planned and systematic stocking activities can be excluded. During 1999 the number of $A$. leptodactylus successively decreased, and in 2000 not one specimen was caught. It is not known, however, if there was an outbreak of the crayfish plague.

\section{North-western Lower Austria («Waldviertel »)}

North of the Danubian Valley, there is a highland formed by slow-weathering rocks of granites and gneiss. This plain, slightly undulatory landscape is dominated by wood, grass- and moorland, and the fields and villages in this rural area are very small. In the "Waldviertel ", as this part of Lower Austria is called (Figure 1), there are many small to medium-sized ponds for rearing common carp (Cyprinus carpio). Some of these ponds go back to the early Middle Ages, when the country had been colonized by monasteries. Even more famous might be the larger ponds and aquaculture facilities near Trebon in the south of the Czech Republic. It is also worth to mention that the running waters in the very northwest corner of the Waldviertel do not drain into the Danube System (and the Black Sea), but into the Moldau or Moldava, and thus the Elbe System (and the North Sea). The Reissbach, the Braunaubach, and the Romaubach in the District of Gmünd are tributaries to the Lainsitz River or Luznice as it is called in the Czech Republic.

Until 1997 the ponds, streams and rivers of this area, like the Herrensee, the Schlossteich, the Reissbach, the Braunaubach, and the Romaubach were inhabited by dense and healthy populations of the noble crayfish, $A$. astacus (compare Figure 3 in PÖCKL, 1999a, C). A. astacus also occurred in smaller carp ponds with a lower density. The north-western Waldviertel was one of the very few distribution centres of $A$. astacus in Austria, and the establishment of a "Native Crayfish Area (NCA) " would have been an important step in the protection of this species.

The management and the fish production of some of these ponds was stopped because of marketing problems, and the ponds were rented to angling clubs. Not much time passed before the first signal crayfish ( $P$. leniusculus) was observed. These observations were made within two years. The signals spread very rapidly in the water courses and ponds within the drainage system of the Reissbach, the Braunaubach, and the Romaubach. Recently no noble crayfish have been caught. We therefore have to face the extinction of $A$. astacus from one of its best distribution centres in Austria.

\section{Merzenstein - aquacultural enterprise}

This aquacultural enterprise near the city of Zwettl, Waldviertel, northern Lower Austria (Figure 1), produced noble crayfish ( $A$. astacus). Several ponds which vary in size between $800 \mathrm{~m}^{2}$ and 6 hectares (total surface: $c$. 16 hectares) had been used to produce common carp (Cyprinus carpio). In 1988 the production of carp was reduced, the production of noble crayfish was successfully intensified.

During spring 1990 in one of the larger ponds the first dying crayfish, showing symptoms of the crayfish plague disease, were observed. From where Aphanomyces astaci has been introduced was unknown; most probably it was introduced by waterfowl, otters (Lutra lutra) or by signal crayfish. During harvesting the crayfish in autumn by draining the ponds the first specimens of $P$. leniusculus were also caught during 1990. The plague was observed in the spring, the signals later in the autumn, but within the same year. As this pond is situated in the vicinity of a public motor road, it can be concluded that the signal crayfish have been introduced by unknown persons. It is most likely that $P$. leniusculus originated from the aquarium trade because specimens of the exotic fish species 
Pseudorasbora parva were also observed in this pond, but had never been stocked by the owner and aquaculture entrepreneur. The signal crayfish acted as vectors for the crayfish plague fungus, and within several weeks the noble crayfish were exterminated completely. The intention to establish an aquacultural enterprise and a noble crayfish hatchery in this area had to be abandoned.

It has been suggested that it should be possible to restock after a plague outbreak if the ponds are drained for harvesting. This is easier said than done. Larger ponds, c. 5-6 ha in surface, can never be drained completely, because there will always be some wet patches where water pores out from the ground and where crayfish can survive. Specimens of $P$. leniusculus were also observed in the affluents of the ponds, and these small surface feeders cannot be drained. Crayfish survive the draining of the ponds in their small affluents, and migrate back to the ponds when the water level rises again.

\section{Neufelder See}

The Neufelder See is a man-made water body, a former open brown coal mine, which is situated in the Burgenland close to the border to Lower Austria (Figure 1) at an altitude of $230 \mathrm{~m}$ above sea level (longitude: $16^{\circ} 23^{\prime} \mathrm{E}$, latitude: $48^{\circ} 52^{\prime} \mathrm{N}$ ). The lake being intensively used for all sorts of recreational activities (bathing, swimming, camping, ball games) has a length of $1.7 \mathrm{~km}$, a width of $0.5 \mathrm{~km}$, a surface area of 100 ha and a maximum depth of $40 \mathrm{~m}$ (mean depth: $20 \mathrm{~m}$ ). The Neufelder See is also used for angling.

When crayfish had been introduced in the former brown coal mine for the first time, is not known. Until 1975 a population of the noble crayfish ( $A$. astacus) was thriving in the lake. Later the animals disappeared from the lake for unknown reasons. The ignorant angling club which manages the Neufelder See stocked three different species of crayfish: noble crayfish ( $A$. astacus), Turkish crayfish ( $A$. leptodactylus), and signal crayfish ( $P$. leniusculus). In 1988 the population density of crayfish was high, and the relationship, as estimated by baited traps and hand nets, was the following: $10 \% A$. astacus, $40 \%$ A. leptodactylus, $50 \%$ P. leniusculus. The three species had coexisted at least for some years. After a further increase in the population density, a massive extinction was observed in 1990. Although the reason has never been discovered accurately, crayfish plague ( $A$. astaci) seems to be most likely. Thereafter crayfish have never been stocked into the Neufelder See. Some crayfish must have survived the disease and the population density increased again.

Extremely remarkable is the fact that not only signal crayfish were caught, but also some Turkish crayfish! The noble crayfish, however, has never been sampled again. The population density of the two species remaining in the lake increased until 1998 when a second collapse was observed. Since then only a few signal crayfish were caught. Recently, their density showed a slowly increasing tendency. Relative population estimates are available from baited traps, but accurate quantitative density estimates are unknown.

\section{Coexistence of native and alien crayfish species}

\section{Confluence of the main course of the Danube River, the Ölhafen and the Neue Donau}

A population of the spiny cheek crayfish, O. limosus, was discovered in the Austrian Danube in 1991, in the Ölhafen in the southeastern part of Vienna («Lobau »), at river-km 1918 (Figure 2). This isolated population may be the result of an unknown translocation by boat-traffic on the Danube River (NESEMANN et al., 1995; PÖCKL, 1999a, c). 


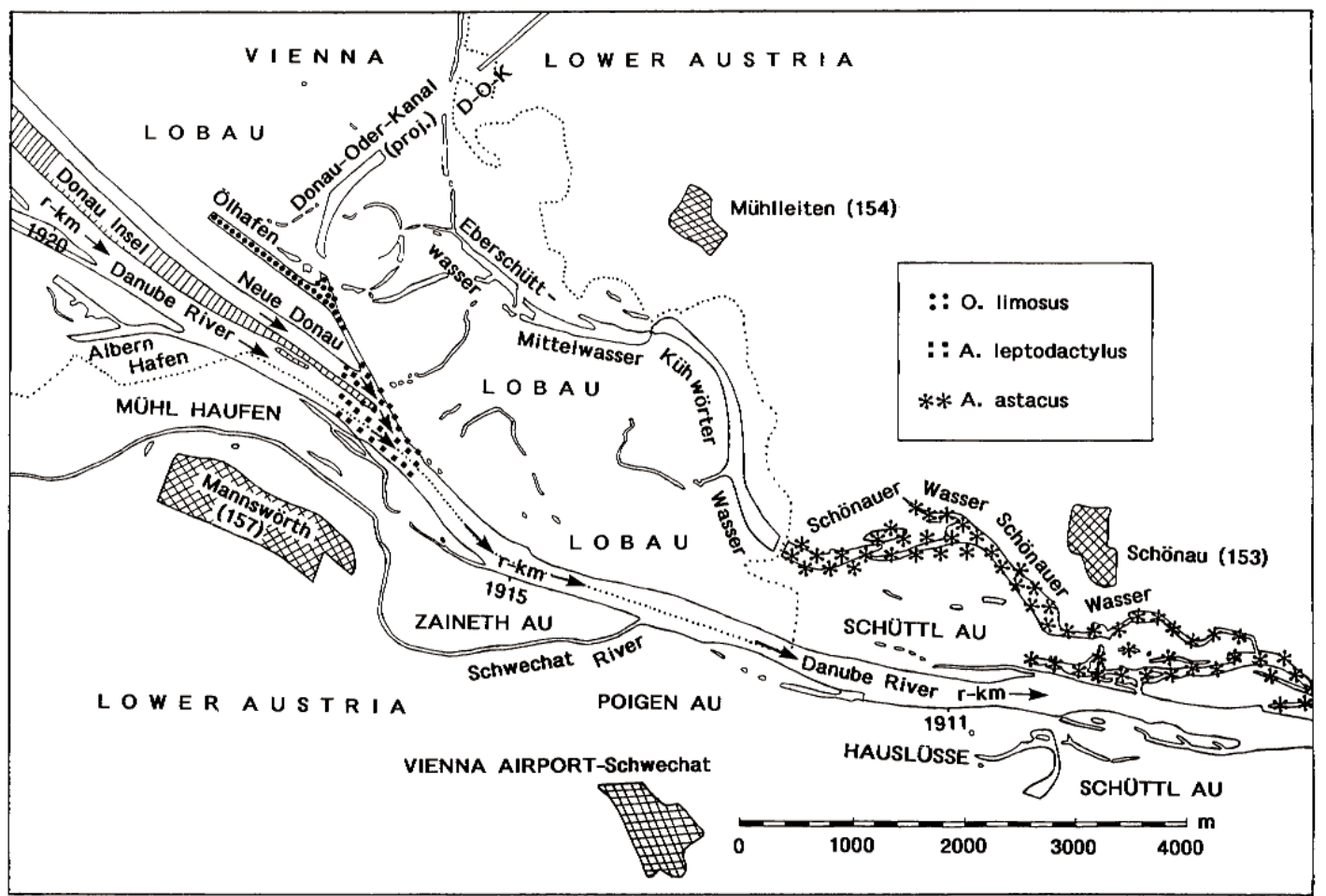

Figure 2

Map of the southeastern part of Vienna («Lobau ») showing details of the main course of the Danube River, the « Donau-Insel », the Neue Donau, and the Ölhafen as well as the neighbouring Lower Austria showing the Schönauer Wasser. The Ölhafen is populated by $\boldsymbol{O}$. limosus, the confluence of the Ölhafen, the Neue Donau, and the main course of the Danube River by $A$. leptodactylus, and the Schönauer Wasser by $A$. astacus.

\section{Figure 2}

Carte géographique du sud-est de Vienne (« Lobau ») avec les détails du fleuve principal du Danube, la « Donau-Insel », le Neue Donau et l'Ölhafen et l'AutricheBas où on trouve le Schönauer Wasser. $O$. limosus habite l'Ölhafen, A. Ieptodactylus le confluent de l'Ölhafen, du fleuve principal du Danube, et du Neue Donau, A. astacus le Schönauer Wasser.

After the Volga, the Danube is the second longest European river (2 $850 \mathrm{~km})$, and the mouth of its estuary on the Black Sea is designated as river-km 0; the centre of Vienna is situated upstream at river-km 1930. The Austrian stretch of the Danube is c. $340 \mathrm{~km}$ in length, and lies between river-kilometres 1880 and 2 220. As the relative difference in altitude is $156 \mathrm{~m}$, the Danube River in Austria is intensively used for producing hydroelectric power (DIEPLINGER et al., 1996; HUMPESCH, 1996; PÖCKL, 1999c).

The Neue Donau in the 21st and 22nd district of Vienna which was began in 1972 because of flood protection and flood regulation is c. $21 \mathrm{~km}$ long and has a width of c. $200 \mathrm{~m}$ (Figure 2). Between the main course of the Danube River which had been regulated between 1869 and 1975 and the Neue Donau there is a long artificial island (material from tunnelling the underground or métro lines) with a maximum width of $250 \mathrm{~m}$, the so-called «Donau-Insel » (Figure 2). This island and the Neue Donau are intensively used by the Viennese people for recreation: swimming, (sun)-bathing, surfing, rowing, cycling, etc. At river-km 1 916.5, the canal leading to the Ölhafen, the Neue Donau and the 
main course of the Danube River meet (Figure 2). In this area specimens of the Turkish crayfish, $A$. leptodactylus, were caught several times. This fact is remarkable because just $1.5 \mathrm{~km}$ upstream from this place, the Ölhafen is densely inhabited by an 0 . limosus population as mentioned above. This is in contrast to small water bodies where a coexistence does not seem to be possible at all. In Vienna, the Danube River, however, has a mean discharge of $1903 \mathrm{~m}^{3}$ per second. Hydrological data are given in Table I. This area which is a riverside forest with many water bodies is a nature conservation reserve of the Federal State of Vienna, called the « Lobau ». From south-eastern Vienna until the border to Slovakia (more than $40 \mathrm{~km}$ ) the Danube River with its backwaters and ox bows, including enormous riverside forests, is conserved as a National Park, called « DonauAuen ».

Table I

Characteristic hydrological data of the Rivers Danube, Morava and Thaya (from ZULKA and LAZOWSKI, 1999). Discharge values in $\mathrm{m}^{3}$ per second.

\section{Tableau I}

Données hydrologiques caractéristiques des Fleuves Danube, Morava et Thaya (d'après ZULKA et LAZOWSKI, 1999). Débit en $\mathrm{m}^{3}$ par seconde.

\begin{tabular}{|c|c|c|c|}
\hline Parameter & $\begin{array}{l}\text { Danube River } \\
\text { (at Vienna) }\end{array}$ & $\begin{array}{l}\text { Morava River } \\
\text { (at Angern) }\end{array}$ & $\begin{array}{c}\text { Thaya } \\
\text { (at Bernhardsthal) }\end{array}$ \\
\hline Highest observed discharge & $\begin{array}{c}14000 \\
\text { in August } 1501\end{array}$ & $\begin{array}{l}1584 \\
\text { in } 1941\end{array}$ & $\begin{array}{c}820 \\
\text { in } 1941\end{array}$ \\
\hline Period of systematic recordings & 1951-1994 & 1951-1994 & $1969-1997$ \\
\hline $\begin{array}{l}\text { Highest discharge during the time } \\
\text { period }(\mathrm{HQ})\end{array}$ & $\begin{array}{c}9699 \\
\text { July } 14^{\text {th }} 1954 \\
\end{array}$ & $\begin{array}{c}940 \\
\text { June } 16^{\text {th }} 1965\end{array}$ & $\begin{array}{c}379 \\
\text { May } 25^{\text {th }} 1985 \\
\end{array}$ \\
\hline $\begin{array}{l}\text { Mean of the highest annual } \\
\text { discharge (MHQ) }\end{array}$ & 5810 & 467 & 160 \\
\hline $\begin{array}{l}\text { Highest annual mean for the time } \\
\text { period (HMQ) }\end{array}$ & 2586 & 189 & 73.5 \\
\hline Daily mean discharge (MMQ) & 1903 & 105 & 37 \\
\hline $\begin{array}{l}\text { Lowest annual mean for the time } \\
\text { period (NMQ) }\end{array}$ & 1402 & 56.7 & 17.1 \\
\hline $\begin{array}{l}\text { Mean of the lowest annual discharge } \\
\text { (MNQ) }\end{array}$ & 840 & 31.5 & 8.0 \\
\hline $\begin{array}{l}\text { Lowest discharge during the time } \\
\text { period (NQ) }\end{array}$ & $\begin{array}{c}504 \\
\text { January } 1^{\text {st }} 1954\end{array}$ & $\begin{array}{c}12.3 \\
\text { August } 8^{\text {th }} 1992 \\
\end{array}$ & $\begin{array}{c}1.7 \\
\text { August } 28^{\text {th }} 1983\end{array}$ \\
\hline $\begin{array}{l}\mathrm{k} 1=\mathrm{MHQ}: \mathrm{MQ} \\
\mathrm{k} 2=\mathrm{MNQ}: \mathrm{MQ} \\
\mathrm{k} 3=\mathrm{MHQ}: \mathrm{MNQ}\end{array}$ & $\begin{array}{l}3.05 \\
0.44 \\
6.92 \\
\end{array}$ & $\begin{array}{c}4.45 \\
0.30 \\
14.83 \\
\end{array}$ & $\begin{array}{c}4.32 \\
0.22 \\
19.86 \\
\end{array}$ \\
\hline$M Q_{\text {month }} / \mathrm{MQ}_{\text {annual }}$ & 1.404 & 1.819 & 1.799 \\
\hline
\end{tabular}

\section{The Schönauer Wasser - a backwater of the Danube River}

The Schönauer Wasser is located 5.5-6.0 km downstream of the above mentioned study site, close to the village of Schönau, Lower Austria. It is a backwater or ox bow on the north bank of the Danube River at river-km 1911 which is connected with the main course during floods (Figure 2). In October 1992 the Schönauer Wasser was stocked with 1600 specimens of the noble crayfish (0+ age group), A. astacus, by the fishing club which manages this water body. The success of this stocking activity, however, was doubtful because the occurrence of the spiny cheek population in the Ölhafen, c. $7 \mathrm{~km}$ upstream the Schönauer Wasser, has already been well known. One year after the first, successful introduction a second stocking activity with $A$. astacus followed. Thereafter the noble 
crayfish population proved to be stable, albeit at a low density level because of the presence of predatory fish, like eel (Anguilla anguilla), pike (Esox lucius) and wels (Silurus glanis). As the survival of $A$. astacus proved to be good, adult specimens were stocked in 1996. Thus, noble crayfish survived for at least several years in the Schönauer Wasser, although $O$. limosus occurs in the drainage system, just $c .7 \mathrm{~km}$ upstream. In this backwater itself, called Schönauer Wasser, $O$. limosus has never been found.

\section{Backwaters or ox bows of the March (Morava) River}

The March or Morava River, the largest left-side tributary to the Danube River enters the Danube River at river-km 1880 after a flow of $344 \mathrm{~km}$ (longitude: $16^{\circ} 58^{\prime} \mathrm{E}$, latitude: $48^{\circ} 10^{\prime} \mathrm{N}$ ). The Lower March River between Hohenau (155 m above sea level) and Theben or Devin (136 m) is the border between Austria and Slovakia. Amongst the rivers of Austria, the Lower Morava River is unique as it is the only real lowland river in that country, classified as a meta-potamal river region (UMWELTBUNDESAMT, 1999; ZULKA and LAZOWSKI, 1999): it has many meanders, back waters and ox bows, some of them being connected with the main course during floods, old riverine forests of considerable size and wet meadows (Figure 3). During regulation work 16 meanders were cut off the main course which thus lost some of its original length, increasing the slope from 0.015 to $0.019 \%$ (WEIGAND and WINTERSBERGER, 1999). The width of the main course is more than $50 \mathrm{~m}$, the width of the flood plain between $360 \mathrm{~m}$ and c. $3000 \mathrm{~m}$. The mean discharge of the Morava River at Angern is $105 \mathrm{~m}^{3}$ per second, but its dynamics are considerable (see below and Table I). The difference in water levels is up to $6 \mathrm{~m}$. The most important tributary to the Morava River is the Thaya or Dyje River with a length of $285 \mathrm{~km}$. At Hohenau, the Thaya enters the Morava River. At Berhardsthal close to Hohenau the mean discharge of the Thaya River is $37 \mathrm{~m}^{3}$ per second (see below and Table I).

Although $O$. limosus was found to inhabit sparsely the main course of the Morava River between Angern and Baumgarten, the Turkish crayfish A. leptodactylus is also recorded to occur sparsely within the same stretch of the river. Encouraged by the successful introduction of $A$. astacus in the Schönauer Wasser, a re-introduction programme concerning the noble crayfish was started in 1999. These backwaters between Baumgarten and Marchegg are downstream the localities where O. limosus has been found. During the annual floods, these backwaters are in connection with the main course. However, the density of the spiny cheek crayfish is extremely low in the Morava River, so that it can hardly be caught using baited traps, but casually some specimens are caught by fishermen using lift-nets. During autumn 2000, specimens of A. astacus were recaptured in the habitats where they had been re-introduced one year before. However, O. limosus has never been recorded in the backwaters, old meanders and ox bows.

\section{DISCUSSION AND CONCLUSIONS}

PÖCKL (2002) presented a draft programme for the conservation of the native crayfish species in Austria and discussed necessary management measures and actions. Whereas similar concepts have been developed for other countries, e.g. Germany (DEHUS et al., 1999), Great Britain (HOLDICH and ROGERS, 1997; HOLDICH et al., 1999), Norway (TAUGBOL and SKURDAL, 1998, 1999), and Sweden (FISKERIVERKET, 1998), PÖCKLs paper highlights the special situation in Austria. The actions include the restoration of aquatic habitats, the facts that the protection of native species must be a national aim in all countries, that mapping and monitoring of crayfish distribution and abundance must to be kept up to date, and that native crayfish areas (NCAs) should be established in all European countries. 


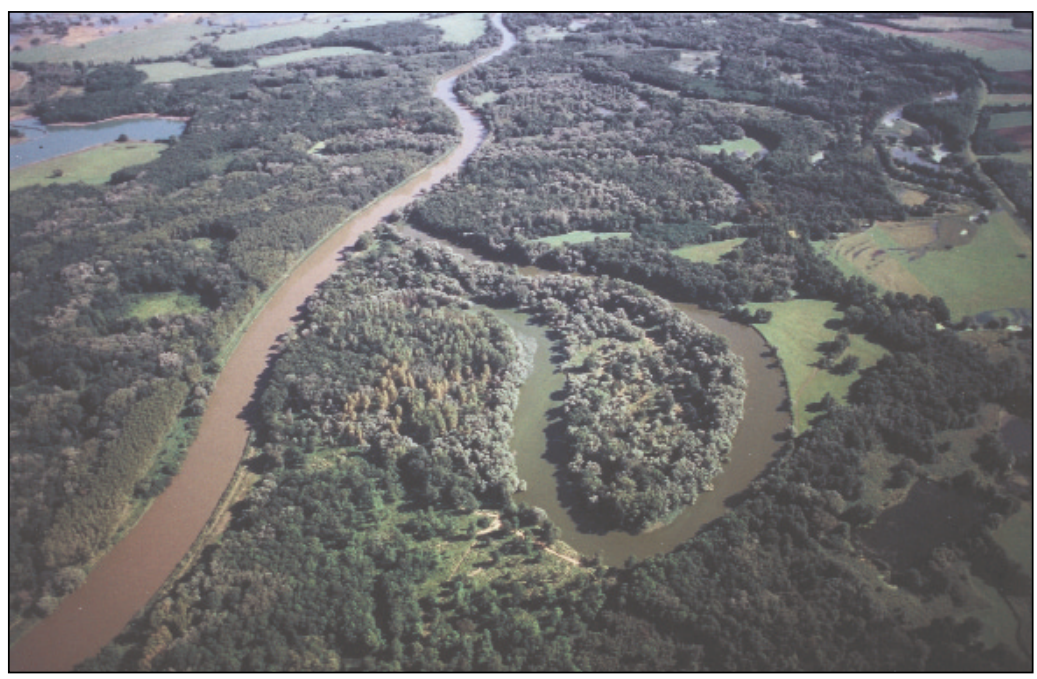

\section{Figure 3}

Aerial view showing the main course of the Morava River (brown water) and a former meander (green water), now being an open back water and the riverside forests. Taken on September 5th 1995 (TBW, G. NAVARA).

\section{Figure 3}

Photographie aérienne qui présente le fleuve principal du Morava (eau brune), et un bras secondaire ancien (eau verte), maintenant ouvert vers le fleuve, et les rives boisées du fleuve. Prise le 5 septembre 1995 (TBW, G. NAVARA).

Most important of all in such a protection effort is, however, to prevent further spread of non-native species of crayfish, especially to the designated NCAs. The struggle includes many different actions: a good legislation and enforcement, good co-operation and coordination between different authority levels, between nature conservation and fisheries managers, the development of methods to eradicate unwanted or nuisance populations of alien crayfish, the re-establishment of native crayfish populations in appropriate water bodies, a sustainable exploitation of native and non-native species, and information to the public (PÖCKL, 2002).

In Austria, the noble crayfish, $A$. astacus, has been successfully re-established in several streams and rivers, ponds, and lakes. Currently, the stone crayfish, $A$. torrentium, and the white-clawed crayfish, $A$. pallipes, which is restricted to a few streams in Carinthia and some lakes in Tyrol, are successfully bred in aquaculture tanks. It is important to have a gene-pool under safe laboratory conditions because the natural populations can easily be wiped out. Breeding of native crayfish species and re-introduction activities are cofinanced by the European Community as "Life Projects " in Austria, e.g. A. pallipes in Carinthia. The latter species is also listed in Annex II of the EC Habitats Directive (PÖCKL, 1999b). SACs (Special Areas of Conservation) have been designated in Carinthia and Tyrol to conserve the local populations of $A$. pallipes. In order to preserve possible intra-specific biodiversity, care is taken not to mix several stocks up. In situ and ex situ methods of preserving the indigenous crayfish fauna are combined in Austria. We also try to teach the public and the Government by several information campaigns. 35000 leaflets have currently been printed to inform landowners, fishermen, anglers, and aquaculturists in Lower Austria. In 2000, the Federal State of Lower Austria published a red data book on decapods and mysid shrimps (PEKNY and PÖCKL, 2000). 


\section{CONCLUSIONS}

From the case studies presented above some conclusions can be drawn.

In small, especially standing water bodies, native crayfish have been displaced rather quickly by alien crayfish. In our opinion this phenomenon is due firstly to the relative small volume of the water bodies studied and secondly to the relative high density of both the native and the alien crayfish. Thus, the interactions between the autochthonous and the invading crayfish are high, and in case of an outbreak of the crayfish plague disease, the concentration of the zoospores is also high. The native crayfish cannot escape the fungus by moving to other types of habitat, and the mortality can reach $100 \%$.

When the water bodies are large (compare Table I showing the characteristic hydrographic data of the Rivers Danube, Morava, and Thaya), when the habitat diversity is high (and not all these habitat types can be colonized by crayfish), when the crayfish density is relatively low due to a high predation pressure (predatory fish like eel, perch, pike, pikeperch, wels, and herons, otters, etc.), a high current velocity, a fishing pressure by man, or to other factors, a coexistence of European and North American species within the same drainage system might be possible. When there is an outbreak of the crayfish plague disease, the concentration of the zoospores will be extremely low because of the huge volume of water, thus allowing the survival of some individuals of the autochthonous crayfish populations in some of the habitat types. When the above mentioned variables large body of water and/or high discharge of water (compare Table I), high diversity and heterogeneity of habitats, low crayfish density - are constant, the observed coexistence within the same drainage system might also be constant for a long period of time. When the crayfish density of both the European and the American species increases and a certain critical level is exceeded which may be different from habitat to habitat, the population can collapse extremely quickly by an outbreak of the plague disease.

Although a coexistence might be possible for a long period of time in larger bodies of water and large rivers which offer a variety of diverse habitats, the variables allowing a coexistence have to be monitored continously. When a marked increase in crayfish density is observed, an adequate population management, including harvesting for human consumption or an increased predation pressure, will urgently be required. When such a management programme is not available at that crucial moment, a quick extinction of the native species must be expected. This means, a coexistence might be possible as suggested by our observations, but the stability of the system has to be monitored. Further observations will teach us whether our hypothesis is confirmed or whether it must be rejected.

\section{ACKNOWLEDGEMENTS}

I wish to thank Dr. Catherine SOUTY GROSSET et Prof. Erick VIGNEUX for improving the French texts.

\section{REFERENCES}

DEHUS P., PHILLIPSON S., BOHL E., OIDTMANN B., KELLER M., LECHLEITNER S., 1999. German conservation strategies for native crayfish species with regard to alien species. In : GHERARDI F. and HOLDICH D.M. (Eds.), Crayfish in Europe as alien species. How to make the best of a bad situation? Crustacean Issues 11. Balkema, Rotterdam. 149-159. 
DIÉGUEZ-URIBEONDO J., SÖDERHÄLL K., 1993. Procambarus clarkii Girard as a vector for the crayfish plague fungus, Aphanomyces astaci, Schikora. Aquaculture and Fisheries Management, 24, 761-765.

DIEPLINGER K., LEBERL S., ZAUNER G., 1996. Biotope management on the Austrian Danube. Archiv für Hydrobiologie, Supplement, 113, 219-228.

EUROPEAN COURT OF JUSTICE, 1994. Case C-131/93, Free movements of goods. Commission of the European Communities versus Federal Republic of Germany (cited from DEHUS et al., 1999).

FISKERIVERKET, 1998. Atgärdsprogram för bevarande av flodkräftan (Astacus astacus L.) (Action plan for the noble crayfish). Report from Fiskeriverket (in Swedish) (cited from TAUGBOL and SKURDAL, 1999).

GHERARDI F., HOLDICH D.M., 1999. Crayfish in Europe as alien species. How to make the best of a bad situation? Crustacean Issues 11. Balkema, Rotterdam. $292 \mathrm{p}$.

HOLDICH D.M., ROGERS W.D., 1997. The white-clawed crayfish, Austropotamobius pallipes, in Great Britain and Ireland with particular reference to its conservation in Great Britain. Bull. Fr. Pêche Piscic., 347, 597-616.

HOLDICH D.M., ROGERS W.D., REYNOLDS J.D., 1999. Native and alien crayfish in the British Isles. In : GHERARDI F. and HOLDICH D.M. (Eds.), Crayfish in Europe as alien species. How to make the best of a bad situation? Crustacean Issues 11 . Balkema, Rotterdam. 221-235.

HUMPESCH U.H., 1996. Case study - the River Danube in Austria. Archiv für Hydrobiologie, Supplement, 113, 239-266.

LINDQVIST O., 1988. Restoration of native European crayfish stocks. Freshwater Crayfish, 7, 6-12.

MC NEELEY J.A., 2000. Global strategy for addressing the problem of invasive alien species. A result of the global invasive alien species (GISP). IUCN - The World Conservation Union. Draft Version. $61 \mathrm{p}$.

MOONEY H.A., HOBBS R.J., 2000. Invasive species in a changing world. Island Press, Washington, D.C. 384 p.

NESEMANN H., PÖCKL M., WITTMANN K., 1995. Distribution of epigean Malacostraca in the middle and upper Danube (Hungary, Austria, Germany). Miscellanea zoologica hungarica, 10, 49-68.

PEKNY R., PÖCKL M., 2000. Flusskrebse und Süßwassergarnelen (Decapoda, Mysidacea) - 1. Fassung 1999. In : Rote Liste ausgewählter Tiergruppen Niederösterreichs. Amt der Niederösterreichischen Landesregierung, Abteilung Naturschutz, St. Pölten. 34-76.

PERRINGS C., WILLIAMSON M., DALAMAZZONE S., 2000. The economics of biological invasions. Elgar, Cheltenham. 249 p.

PIMENTEL D., LACH L., ZUNIGA R., MORRISON D., 2000. Environmental and economic costs of non-indigenous species in the United States. BioScience, 50, 53-65.

PÖCKL M., 1999a. Distribution of crayfish species in Austria with special reference to introduced species. Freshwater Crayfish, 12, 733-750.

PÖCKL M. 1999b. Freshwater crayfish in the legislation of Austria: federal, national and international laws. Freshwater Crayfish, 12, 899-914.

PÖCKL M., 1999c. The distribution of native and introduced species of crayfish in Austria. Freshwater Forum, 12, 4-17.

PÖCKL M., 2002. Draft program for the conservation of native crayfish species in Austria. Freshwater Crayfish, 13, 221-232.

SÖDERBACK B., 1995. Replacement of the native crayfish Astacus astacus by the introduced species Pacifastacus leniusculus in a Swedish lake: possible causes and mechanisms. Freshwater Biology, 33, 291-304.

SPITZY R., 1971. Resistente amerikanische Krebse ersetzen die europäischen, der Krebspest erliegenden Arten. Salzburgs Fischerei, 2, 18-25.

SPITZY R., 1973. Crayfish in Austria, history and actual situation. Freshwater Crayfish, 1, 9-14. 
TAUGBOL T., SKURDAL J., 1998. Forslag til forvaltningsplan for kreps (Proposal to a national management plan for crayfish). Utredning for DN 1998-1 (in Norwegian) (cited from TAUGBOL and SKURDAL, 1999).

TAUGBOL T., SKURDAL J., 1999. The future of native crayfish in Europe: How to make the best of a bad situation? In : GHERARDI F. and HOLDICH D.M. (Eds.), Crayfish in Europe as alien species. How to make the best of a bad situation? Crustacean Issues 11. Balkema, Rotterdam. 271-279.

UMWELTBUNDESAMT, 1999. Fließende Grenzen : Lebensraum March - Thaya - Auen. Umweltbundesamt Wien. $384 \mathrm{p}$.

WEIGAND E., WINTERSBERGER H., 1999. Gewässer. In: Fließende Grenzen : Lebensraum March-Thaya-Auen. Umweltbundesmat Wien. 109-128.

ZULKA K.P., LAZOWSI W., 1999. Hydrologie. In : Fließende Grenzen : Lebensraum MarchThaya-Auen. Umweltbundesamt Wien. 24-50. 